\title{
Developing a math textbook using realistic mathematics education approach to increase elementary students' learning motivation
}

\author{
Jesi Alexander Alim ${ }^{1 *}$, Neni Hermita ${ }^{1}$, Melvi Lesmana Alim ${ }^{2}$, Tommy Tanu Wijaya ${ }^{3}$, \\ Jerito Pereira $^{3}$ \\ ${ }^{1}$ Universitas Riau. Jl. HR Soebrantas Km 12,5 Pekanbaru, Riau 28293 - Indonesia \\ ${ }^{2}$ Universitas Pahlawan. Jl. Tuanku Tambusai No. 23 Bangkinang Kota, Provinsi Riau, Indonesia, 28412 \\ ${ }^{3}$ Guangxi Normal University. Diecai District, Guilin, Guangxi, China \\ * Corresponding Author. E-mail: jesi.alexander@lecturer.unri.ac.id
}

Received: 14 March 2021; Revised: 2 April 2021; Accepted: 2 May 2021

\begin{abstract}
This study aims to develop an appropriate and practical math textbook in the unit of the Least Common Multiple (LCM) and the Greatest Common Divisor (GCD) using Realistic Mathematics Education (RME) in order to increase elementary students' learning motivation. This is a Research and Development (RnD) type of study with the Plomp model. A mathematician and a teacher assessed the validity of the textbook. The practicality of the textbook was assessed by two teachers and 15 students using questionnaires. The students' motivation was assessed by the students using questionnaires as well. The results showed that the textbook was appropriate with the average of $83.32 \%$, the responden results from the students' views was practical with the average of $82.33 \%$ and very practical with the average of 87.6 from the teachers' view. This study also found that the textbook increased the students' learning motivation by $6.45 \%$.
\end{abstract}

Keywords: Math Textbook, RME, Learning Motivation.

How to Cite: Alim, J., Hermita, N., Alim, M., Wijaya, T., \& Pereira, J. (2021). Developing a math textbook using realistic mathematics education approach to increase elementary students' learning motivation. Jurnal Prima Edukasia, $\quad 9(2), \quad$ 198-201. doi:https://doi.org/10.21831/jpe.v9i2.39393

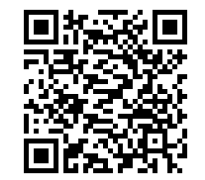

\section{Introduction}

The math teaching and learning activities should focus on mathematics' basic concepts (Wijaya, Ying, \& Purnama, 2020). The basic concepts of mathematics are very important because if students master the basic concepts, students will have no difficulty in solving math problems even though the teacher changes the form of the problems or changes the difficulty level of the problems (Hermita et al., 2020; Tan et al., 2020). Students should learn the basic concepts from an early age. It helps students to understand the basic concepts for the next step (Clements \& Sarama, 2011; Russo et al., 2020) because the potential of each student's involves the mathematical skills and understanding in various situations (Badraeni et al., 2020; Cunhua et al., 2019), and effectively provides positive changes for students for the next step (Anthony \& Walshaw, 2016; Markovits, 2011).

Elementary students consider learning the LCM and GCD very difficult. Many students experience failure in understanding the concepts, especially on story problems (Fatih, 2020; Marzuki, 2017). The main cause of the failure to understand LCM and GCD's concepts is that the learning activities are only in the forms of remembering numbers, studying computational aspects, and applying formulas (Fauzan et al., 2013). In several regions in Indonesia, the teachers still use conventional methods (Hermita et al., 2019; Wijaya, Ying, Chotimah, et al., 2020; Zulnaidi et al., 2020). The teachers' classroom decision has not considered students' potential, teaching/learning materials, students' characteristics, models, and learning resources (Jalinus \& Alim, 2019).

Teachers usually only rely on textbooks in teaching LCM in elementary school. The textbook presented in Figure 1 shows that the teaching/learning materials are arranged by giving examples and answers to the problems without any activity to find the concept of the teaching/learning materials. Such a textbook does not help the students to construct knowledge. In fact, the quality of a textbook affects students' achievement and teaching/learning efficiency (Reys \& Reys, 2006; Stein et al., 2007). Books play an important role in the learning process of students and in the teaching process of teachers (Cai \& 
Jurnal Prima Edukasia, 9 (2), 2021 - 194

Jesi Alexander Alim, Neni Hermita, Melvi Lesmana Alim, Tommy Tanu Wijaya, Jerito Pereira

Jiang, 2017; Fan \& Kaeley, 1998; Reys et al., 2010). Teachers often rely on math textbooks in the process of designing lessons to be implemented in the classroom.
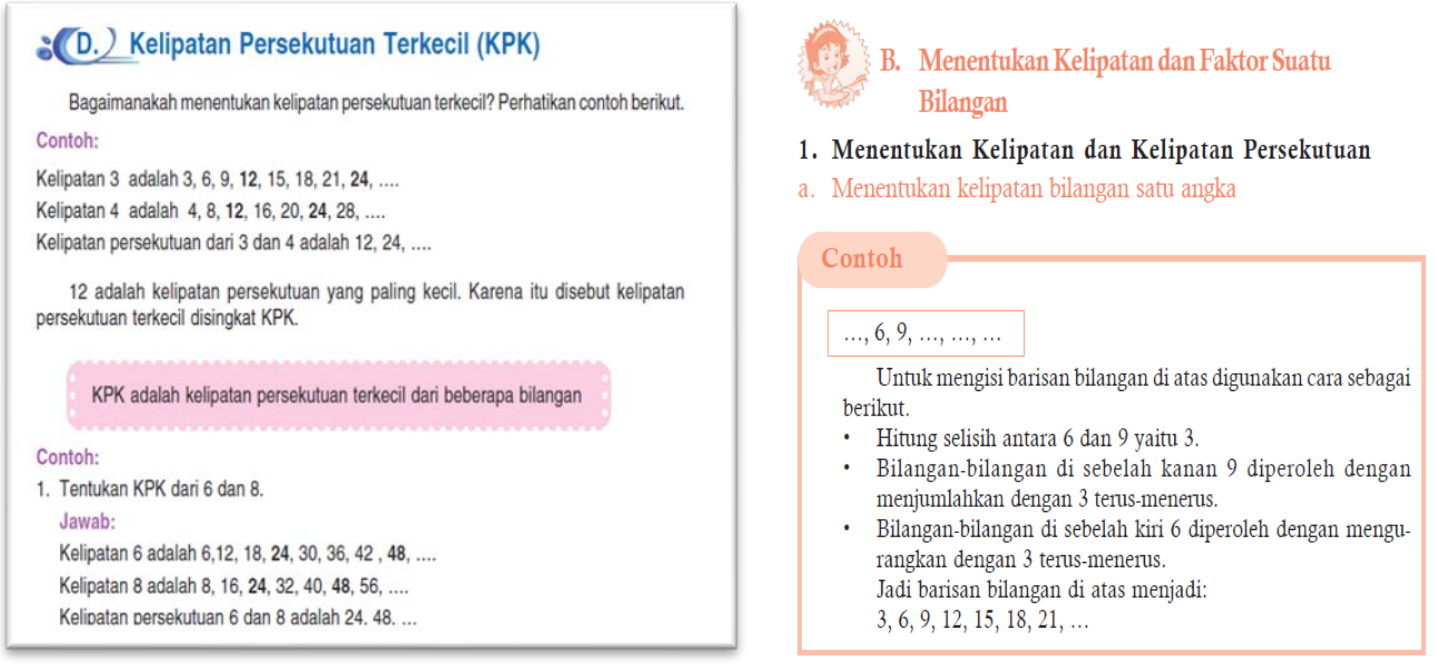

Figure 1. The math textbook for 4th grader in the unit of LCM and GCD

The quality of textbooks affects the students' learning outcomes and achievements, and the teachers' teaching efficiency (Heyder et al., 2020; Reys \& Reys, 2006). Textbooks play an important role in the learning process of students and in the teaching process of teachers (Fan et al., 2013; Fatkhiyani \& Dewi, 2020). Teachers thus far use math textbooks in designing the learning process in the classroom. The use of bad textbooks will cause the students to have low mathematical abilities and unable to work on various mathematics problems.

Mathematics teaching/learning materials are related to real-life human activities (Kulsum et al., 2019; Zhang et al., 2020), so mathematics learning activities should be related to the students' daily life (Jalinus \& Alim, 2018). When teaching, teachers need to tell that learning mathematics is very important for human life. Mathematics learning using RME approach that relates mathematics learning students' daily life can improve students' mathematical abilities in various aspects. Mathematics learning using RME related- approach is still not fully implemented in elementary schools. The observation results showed that the researchers carried out in several elementary schools in Pekanbaru showed that most teachers only used textbooks recommended by the education office. The teachers also rarely or never used other learning resources. The mathematics teaching/learning materials presented are still very procedural and glued on formulas (Schneider, 2002) so that students only remember formulas to solve problems related to mathematics, especially on the unit of the LCM the GCD. The slow learners will have difficulty understanding the LCM and GCD concept than the fast learner because the concept is very complex (Fachrurazi, 2017).

Before learning the LCM and the GCD, students must master the basic concepts of arithmetic operations like addition, subtraction, division, multiplication, and even exponentiation. Addition and subtraction are the basic concepts in solving mathematical problems. Division is the concept used to determine prime factorization to find out the GCD of two numbers. Multiplication is the concept used to determine the multiple of two numbers to find out the LCM. When students solve mathematical problems using prime factorization, students often make mistakes in determining which concepts are used to find out the LCM and GCD. Also, when solving the LCM and GCD problems, many students make mistakes in determining the multiples and prime factors of a number. This condition is similar to the research conducted by Ningtyas which found that students did not understand the LCM and GCD concept because they did not master the concepts of multiplication, prime factorization, algorithms to find out the LCM and GCD, and distinguishing prime and non-prime numbers (Ningtyas, 2015). The study of Fachrurazi of fifth graders found that $41.15 \%$ of students met the minimum complete criteria in the LCM and GCD unit, and the other $53.85 \%$ of students did not pass in the minimum completeness criteria (Fachrurazi, 2017).

Learning motivation is someone's effort in his/her learning process to get the best achievement or knowledge. Learning motivation is considered a psychological factor that plays an important role in 
encouraging someone (Barkatsas et al., 2009; Dikovic, 2009). Learning motivation will bring someone to achieve the goal or the best result (Ingwarni, 2018). When learning motivation increases, a person will not give up on the challenges or problems he/she faces. In other words, he/she feels challenged to complete and achieve the goals. Students who have learning motivation will have a lot of enthusiasm and energy to learn and keep trying to get new knowledge, especially elementary students who can learn new things easily. In conclusion, elementary students should have high learning motivation, and teachers can create an atmosphere and learning media that can increase the students' learning motivation.

To overcome the problems, the teachers should develop a math textbook using RME approach. Teacher performance affects student achievement (Sanberk \& Bağiş, 2016) because one of the factors that affect student achievement is teacher factors (Bertram \& Pascal, 2016; Sun et al., 2015). Teachers as educators must improve learning effectiveness in the early school years (Anthony \& Walshaw, 2016) because high-quality classroom teaching and learning contribute positively to the students' academic achievement, behavior, and learning motivation (Salminen et al., 2012).

\section{Methods}

This study used Research and Development (RnD) approach. The development of the textbook used the Plomp model. The development phases of the Plomp model are illustrated below by McCenney (Plomp, 2013).

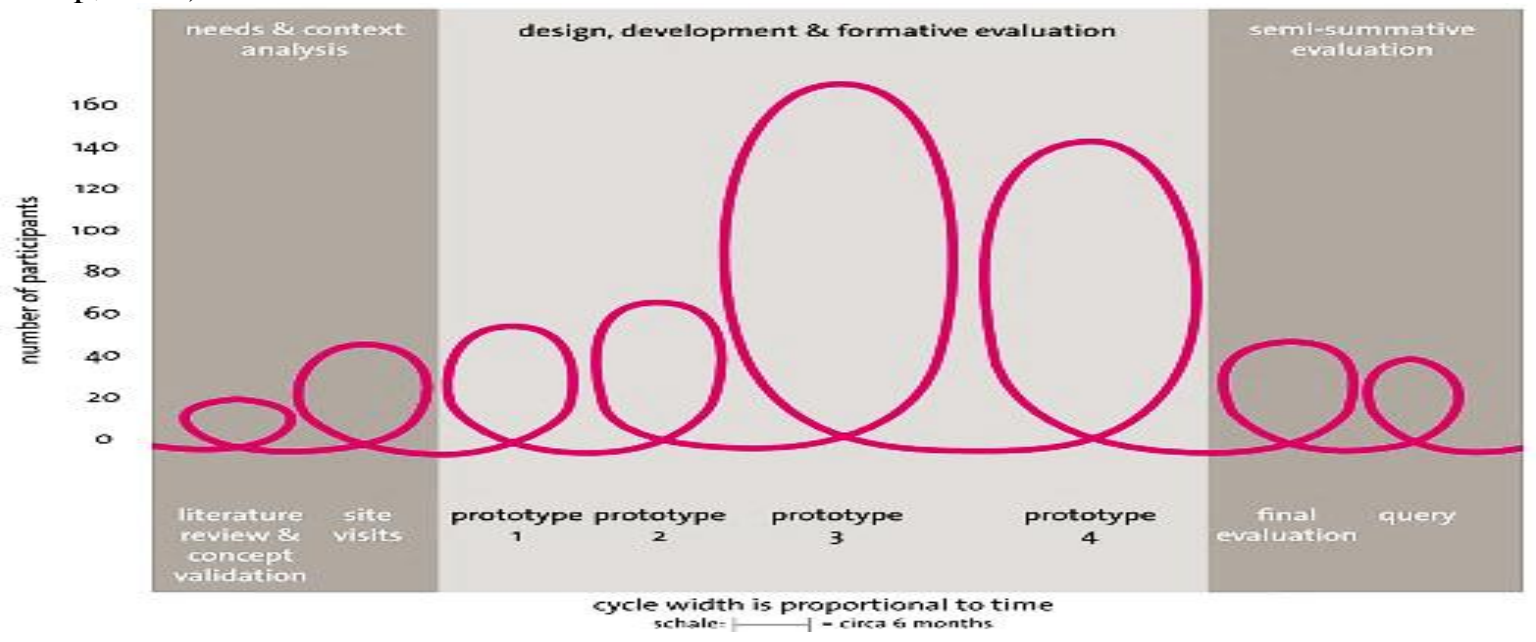

Figure 2. McCenney's development phases in Plomp and Nieveen (2007)

The development phase of the textbook using the Plomp model were as following:

Preliminary research

Preliminary research is a preliminary analysis. The aim of the preliminary analysisis to design teaching/learning materials that canbe expanded/described and improved in the design implementation.

Prototypeing phase

In this stage, the prototype of the textbookwas designed using RME approach. The researchers performed three activities in this phase (a) designing the prototype; (b) conducting a formative evaluation; and (c) revising the prototype.

Assessmentphase

The assessment phase was a summative evaluation stage in which the prototype 3 was tested for the effectiveness afterthe validity test and practicality test. The aim of this assessment phase was to determine the extent to which the textbook provided the desired results. An expert assessed the textbook on 4 aspects which content, appearance, didactic, and language. The expert also assessed the textbook on 4 aspects which attractiveness, process, convenience, and time efficiency. The expert performed assessmentusing a questionnaire that consisted of 5 points for every aspect. 
The researchers conducted a revision based on the assessment, and the researchers then created the prototype 4, which was a valid, practical and efficient textbook in the unit of the LCM and GCD. The expert is a doctor of Riau University.

Analysis of the Students' Learning Motivation

The data of the students' learning motivationwere analyzed through 4 criteria in the Table 4 . The data were derived twice (pretest-postest) using questionnaires distributed to 25 students. The data were then processed using the Wilcoxon test and t-test to compare the pretest and post-test scores. This study hypothesized that the students' learning motivation increased after the teacher used the RME-based math textbook to teach the LCM and GCD.

Table 1. The Data Collection Of The Students' Learning Motivation

\begin{tabular}{cccc}
\hline Sample & Pretest & Treatment & Postest \\
\hline Random cluster & $\mathrm{O}^{1}$ & $\mathrm{X}$ & $\mathrm{O}^{2}$ \\
\hline
\end{tabular}

\section{Results and Discussion}

The preliminary analysis or preliminary research was a very important stage in initiating this research. Based on the preliminary analysis, the researchers found the importance of developing a RMEbased math textbook.

The design of the textbook

To make the textbook, the researchers designed the teaching/learning materials on the LCM and GCD unit. These teaching/learning materialscontained the learning objectives and a set of student activities. These activities were about how students learn and solve the given contextual problems. Below is the design of the textbook.

The cover and layout design

The textbook's cover and layout were made as attractive as possible to increase the students' interest in learning the LCM and GCD (Figure 3). The design included the cover design, font, spacing, color, etc.

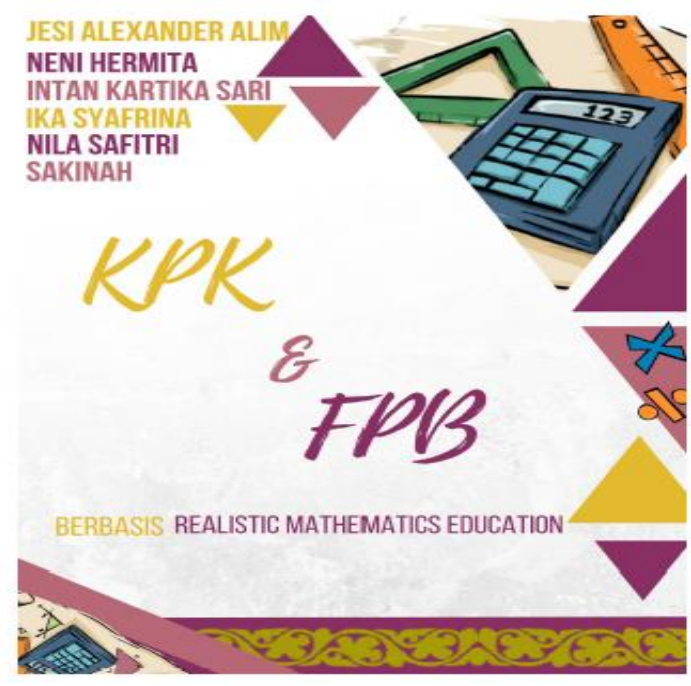

Figure 3. The cover design of the textbook

The teaching/learning materials in the unit of the LCM and the GCD

The teaching/learning materials contained several student activities (Figure 4 and Figure 5). In learning the LCM and GCD, the first thing that the students must understand is the concept of multiple and common multiple. As a result, the LCM is taught first. After the students understand the concept of multiple and common multiple, the students learn the GCD. In learning GCD, the first thing that the students must understand is the concept of factors of a number and common factor. 
Jurnal Prima Edukasia, 9 (2), 2021 - 197

Jesi Alexander Alim, Neni Hermita, Melvi Lesmana Alim, Tommy Tanu Wijaya, Jerito Pereira

CONCEPT MAP

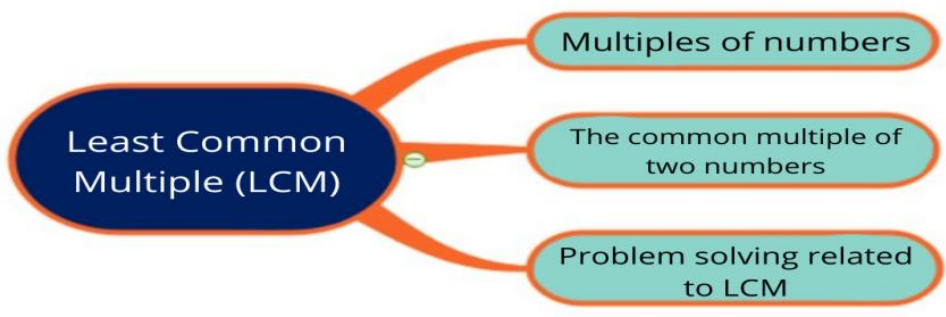

Figure 4. The Concept Map of the LCM

\section{CONCEPT MAP}

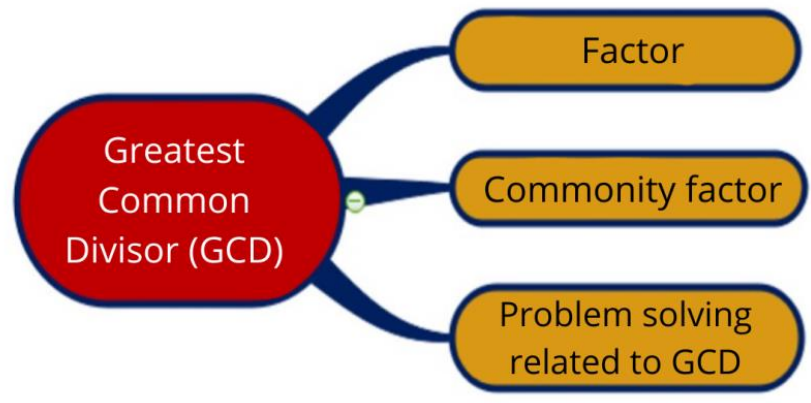

Figure 5. The Concept Map of the GCD

The contents of teaching/learning materials in the unit of the LCM and the GCD
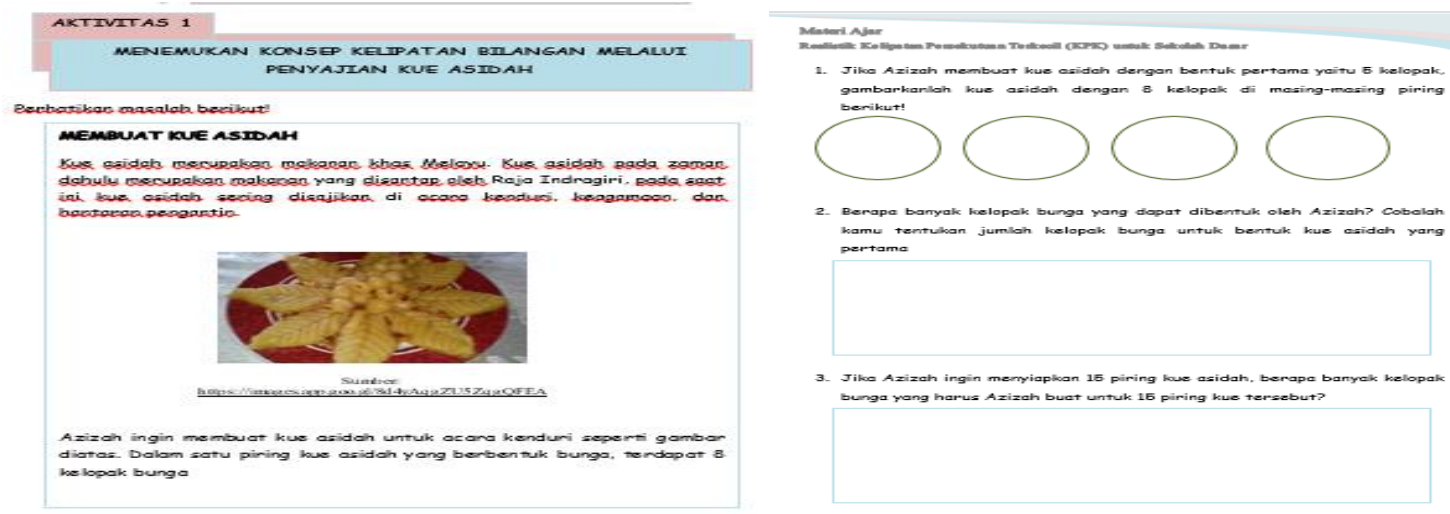

Figure 6. Teaching/learning materials

The problems presented in the textbook (Figure 6) were related to the Malay culture of Riau such as how to make Asidah cake (which is a Malay cake).

The validity of the textbook

A mathematician and a teacher assessed the validity of the textbook. The assessment from both experts was used by to improve the quality of the textbook. After the textbook revision (prototype I), the researchers conducted a trial. The results of the validity test from the experts are presented in the Table 2.

Table 2 shows that the textbook interpretation result is very appropriate. With a validity value average of $83.32 \%$, which means the textbook is proper to be used. 
Jurnal Prima Edukasia, 9 (2), 2021 - 198

Jesi Alexander Alim, Neni Hermita, Melvi Lesmana Alim, Tommy Tanu Wijaya, Jerito Pereira

Table 2. The textbook validation

\begin{tabular}{clcc}
\hline No. & Aspects & Validity Value $(\%)$ & Interpretation \\
\hline 1. & Contents & 75 & Appropriate \\
2. & Didactic & 85.4 & Very appropriate \\
3. & Language & 85.4 & Very appropriate \\
4. & Appearance & 87.5 & Appropriate \\
\hline & Average & 83.32 & Very appropriate \\
\hline
\end{tabular}

The practicality of the textbook

The researchers distributed questionnaires to the teachers and students to measure the practicality of the textbook so that the researchers knew how practical the book can be used in classrooms. The results of the practicality test from the teachers are presented in the Table 3.

Table 3. The practicality of the textbook from the teachers' view

\begin{tabular}{clcc}
\hline No. & \multicolumn{1}{c}{ Aspect } & Practicality Value $(\%)$ & Interpretation \\
\hline 1. & Attractiveness & 84.4 & Practical \\
2. & Process of Use & 88.7 & Very Practical \\
3. & Ease of Use & 87.5 & Very Practical \\
4. & Time efficiency & 89.6 & Very Practical \\
\hline & Average & 87.6 & Very Practical \\
\hline
\end{tabular}

Table 3 shows that the textbook is very practical from the teachers' view with the practicality value average of $87.6 \%$. That means the textbook is very efficient and very easy tounderstand so that the teachers in teaching can use it. The results of the practicality test from the students are presented in Table 4.

Tabel 4. The practicality of the textbook from the students' view

\begin{tabular}{clccc}
\hline No. & \multicolumn{1}{c}{ Aspect } & Average & Percentage & Interpretation \\
\hline 1. & Direction & 3.40 & 85.06 & Very Practical \\
2. & Time efficiency & 3.03 & 75.86 & Practical \\
3. & Attractiveness & 3.36 & 83.90 & Practical \\
4. & Ease of Understanding & 3.22 & 80.60 & Practical \\
5. & Benefits & 3.30 & 82.41 & Practical \\
\hline \multicolumn{2}{r}{ Total Average } & 3.29 & 82.33 & Practical \\
\hline
\end{tabular}

Table 4 shows that the textbook is practical from the students' view with a practicality value average of $82.33 \%$. That means the textbook can be used for students who have high, medium and low abilities.

The students' learning motivation

Table 5. The students' learning motivation before and after using the textbook

\begin{tabular}{lclcc}
\hline \multirow{2}{*}{ Aspect } & \multicolumn{2}{c}{ Before } & \multicolumn{2}{c}{ After } \\
\cline { 2 - 5 } & Percentage & Interpretation & Percentage & Interpretation \\
\hline Ability to understand mathematics & $78 \%$ & High & $83 \%$ & Very High \\
The ability to work together & $75 \%$ & High & $86 \%$ & Very High \\
Able to manage emotions well & $81 \%$ & Very High & $88 \%$ & Very High \\
Able to interpret mathematics well & $79 \%$ & High & $82 \%$ & Very High \\
\hline \multicolumn{1}{c}{ Average } & $78.3 \%$ & High & $84.75 \%$ & Very High \\
\hline
\end{tabular}

Table 5 scores given by respondents shows that the textbook can increase the students' learning motivation by $6.45 \%$ which means very high. Before using the textbook, there was only one aspect of the students' motivation that was considered very high. After using the textbook, all the aspects were considered very high. To see the impact of the textbook on the students' motivation, the researchers conducted a t-test.

The result of the t-test was the Asymp.Sig. (2-tailed) 0.000. It was less than 0.05. It meant that the $\mathrm{H} 0$ was rejected. In conclusion, the students' learning motivation increased after the teacher used the RME-based math textbook to teach the LCM and GCD. It gave a good effect on the students' learning motivation. 
When students were given the textbook, the teacher saw the students were excited and curious about the new textbook. The students actively discussed and worked on the LCM and GCD problems. Teaching and learning activities became more interesting, and the students were very excited. Moreover, the previous textbook as the main learning resource in elementary school did not contain all aspects of knowledge, so it is necessary to develop a textbook using the RME approach or other approaches.

Tabel 6. The result of the t-test

\begin{tabular}{ll}
\hline Statistics Test ${ }^{\text {a }}$ & $-4.019^{\mathrm{b}}$ \\
\hline $\mathrm{Z}$ & .000 \\
Asymp. Sig. (2-tailed) & \\
a. Wilcoxon Signed Ranks Test & \\
b. Based on negative ranks. & \\
\hline
\end{tabular}

\section{Conclusion}

The RME-based math textbook to teach the LCM and GCDin this study is appropriate because it meets the criteria that are reflecting the state of the art knowledgeandin accordance with the key principlesof RME approach. The textbook is also practical because the results of this study are in accordance with the initial hypothesis. The textbook can increase the students' learning motivation by $6.45 \%$. The textbook gives a significant impact on the students' learning motivation based on the t-test results, this study employed one sample treatment group pre-test post-test only. Thus, the effects of training could be present in the post-test.

This study is limited to the development of an RME-based math textbook to teach the LCM and GCD. An RME-based math textbook can be further developed by using a pretest-postest design control group to find out the effectiveness an RME-based math textbook to teach other mathematical concepts.

\section{References}

Anthony, G., \& Walshaw, M. (2016). Mathematics education in the early years. In T. Meaney, O. Helenius, M. L. Johansson, T. Lange, \& A. Wernberg (Eds.), Contemporary Issues in Early Childhood (Vol. 10, Issue 2). Springer International Publishing. https://doi.org/10.1007/978-3319-23935-4

Badraeni, N., Pamungkas, R. A., Hidayat, W., Rohaeti, E. E., \& Wijaya, T. T. (2020). Analisis kesulitan siswa berdasarkan kemampuan pemahaman matematik dalam mengerjakan soal pada materi bangun ruang sisi datar. Jurnal Cendekia : Jurnal Pendidikan Matematika, 4(1), 247253. https://doi.org/10.31004/cendekia.v4i1.195

Barkatsas, A. (Tasos), Kasimatis, K., \& Gialamas, V. (2009). Learning secondary mathematics with technology: Exploring the complex interrelationship between students' attitudes, engagement, gender and achievement. Computers and Education, 52(3), 562-570. https://doi.org/10.1016/j.compedu.2008.11.001

Bertram, T., \& Pascal, C. (2016). Early childhood policies and systems in eight countries. In Eces Iea. Springer International Publishing. https://doi.org/10.1007/978-3-319-39847-1

Cai, J., \& Jiang, C. (2017). An analysis of problem-posing tasks in Chinese and US elementary mathematics textbooks. International Journal of Science and Mathematics Education, 15(8), 1521-1540. https://doi.org/10.1007/s10763-016-9758-2

Clements, D. H., \& Sarama, J. (2011). Early childhood mathematics intervention. Science, 333(6045), 968-970. https://doi.org/10.1126/science.1204537

Cunhua, L., Ying, Z., Qunzhuang, O., \& Wijaya, T. T. (2019). Mathematics course design based on six questions cognitive theory using hawgent dynamic mathematic software. Journal On Education, 2(1), 36-44. http://jonedu.org/index.php/joe/article/view/266

Dikovic, L. (2009). Implementing dynamic mathematics resources with geogebra at the college level. International Journal of Emerging Technologies in Learning, 4(3), 51-54. https://doi.org/10.3991/ijet.v4i3.784

Fachrurazi, F. (2017). Pembelajaran matematika realistik di sekolah dasar pada materi FPB dan KPK dengan model penyajian paket makanan. Al Khawarizmi: Jurnal Pendidikan Dan Pembelajaran 
Matematika, 1(2), 113-122.

Fan, L., \& Kaeley, G. S. (1998). The influence of textbooks on teaching strategies: An empirical study. The American Educational Research Association (AERA) Annual Meeting, 13(4).

Fan, L., Zhu, Y., \& Miao, Z. (2013). Textbook research in mathematics education: Development status and directions. ZDM - International Journal on Mathematics Education, 45(5), 633-646. https://doi.org/10.1007/s11858-013-0539-x

Fatih, M. (2020). Pengembangan bahan ajar puzzle pada matematika berbasis realistik materi KPK dan FPB (Studi pada kelas 5 SDN Bendogerit 1 Kota Blitar). Briliant: Jurnal Riset Dan Konseptual, 5(2), 348. https://doi.org/10.28926/briliant.v5i2.348

Fatkhiyani, K., \& Dewi, R. A. K. (2020). The development of the textbook of basical concept IPA contained ethnoscience. Jurnal Prima Edukasia, 8(2), 156-165.

Fauzan, A., Plomp, T., \& Gravemeijer, K. (2013). The development of an RME-based geometry course for Indonesian primary schools. Educational Design Research - Part B: Illustrative Cases, 159-178.

Hermita, N., Alpusari, M., Noviana, E., Kurniaman, O., Widyanthi, A., \& Suhandi, A. (2019). A study of prospective primary school teachers' alternatif conception in heat and temperature. Journal of Physics: Conference Series, 1351(1), 012072. https://doi.org/10.1088/1742$6596 / 1351 / 1 / 012072$

Hermita, N., Ningsih, H. S., Alim, J. A., Alpusari, M., Putra, Z. H., \& Wijaya, T. T. (2020). Developing science comics for elementary school students on animal diversity. Solid State Technology, 63(1s). http://solidstatetechnology.us/index.php/JSST/article/view/3093

Heyder, A., Südkamp, A., \& Steinmayr, R. (2020). How are teachers' attitudes toward inclusion related to the social-emotional school experiences of students with and without special educational needs? Learning and Individual Differences, 77(July 2018), 101776. https://doi.org/10.1016/j.lindif.2019.101776

Ingwarni, S. (2018). Developing the socioculture-based thematic-integrative learning module for improving the learning motivation and the critical thinking. Jurnal Prima Edukasia, 6(2), 157165. https://doi.org/10.21831/jpe.v6i2.9447

Jalinus, J., \& Alim, J. A. (2019). Quality review of computer based interactive mathematics learning media on geometry topics in flat fields for elementary students. Proceedings of the UR International Conference on Educational Sciences, 397-407. https://ices.prosiding.unri.ac.id/index.php/ICES/article/view/7963

Jalinus, J., \& Alim, J. A. (2018). Development of interactive computer based media for learning mathematics on greatest common divisor (GCD) and least common multiple (LCM) topics. Proceedings of the UR International Conference on Educational Sciences, 978-979. https://ices.prosiding.unri.ac.id/index.php/ICES/article/view/6612

Kulsum, S. I., Hidayat, W., Wijaya, T. T., \& Kumala, J. (2019). Analysis on high school students' mathematical creative thinking skills on the topic of sets. Jurnal Cendekia : Jurnal Pendidikan Matematika, 03(02), 431-436. https://doi.org/https://doi.org/10.31004/cendekia.v3i2

Markovits, Z. (2011). Beliefs hold by pre-school prospective teachers toward mathematics and its teaching. Procedia - Social and Behavioral Sciences, 11, 117-121. https://doi.org/10.1016/j.sbspro.2011.01.045

Marzuki, M. (2017). Prestasi belajar kelipatan persekutuan terkecil dan faktor persekutuan terbesar dengan mengunakan alat bantu dekak-dekak pada siswa kelas IV SD Negeri 4 Bireuen. Jurnal Pendidikan Dasar (JUPENDAS), 2(1). http://www.jfkip.umuslim.ac.id/index.php/jupendas/article/view/223

Ningtyas, R. (2015). Penyebab kesalahan dalam menyelesaikan KPK dan FPB. EKUIVALENPendidikan Matematika, 15(2). https://doi.org/10.37729/ekuivalen.v15i2.2168

Plomp, T. (2013). Educational design research: An introduction. In N. Nieveen \& T. Plomp (Eds.), Educational design research - Part A: An introduction (pp. 10-51). Netherlands Institute for Curriculum Development (SLO). http://international.slo.nl/publications/edr/ 
Plomp, T., \& Nieveen, N. (2007). An introduction to educational design research. Proceedings of the Seminar Conducted at the East China Normal University, Shanghai (PR China), 23-26.

Reys, B. J., \& Reys, R. E. (2006). The development and publication of elementary mathematics textbooks: Let the buyer beware! Phi Delta Kappan, 87(5), 377-383. https://doi.org/10.1177/003172170608700510

Reys, B. J., Reys, R. E., \& Rubenstein, R. (2010). Mathematics curriculum: Issues, trends, and future directions, 72nd yearbook. National Council of Teachers of Mathematics.

Russo, J., Bobis, J., Sullivan, P., Downton, A., Livy, S., McCormick, M., \& Hughes, S. (2020). Exploring the relationship between teacher enjoyment of mathematics, their attitudes towards student struggle and instructional time amongst early years primary teachers. Teaching and Teacher Education, 88, 102983. https://doi.org/10.1016/j.tate.2019.102983

Salminen, J., Lerkkanen, M.-K., Poikkeus, A.-M., Pakarinen, E., Siekkinen, M., Hännikäinen, M., Poikonen, P.-L., \& Rasku-Puttonen, H. (2012). Observed classroom quality profiles of kindergarten classrooms in Finland. Early Education and Development, 23(5), 654-677. https://doi.org/10.1080/10409289.2011.574267

Sanberk, İ., \& Bağiş, S. (2016). How do third-grade students and their teachers construe each other? International Electronic Journal of Elementary Education, 8(4), 559-572.

Schneider, M. (2002). "Do school facilities affect academic outcomes?"National Clearinghouse for Educational Facilities. Building, 75(October), 2-19.

Stein, M. K., Remillard, J., \& Smith, M. S. (2007). How curriculum influences student learning. Second Handbook of Research on Mathematics Teaching and Learning, 1(1), 319-370.

Sun, J., Rao, N., \& Pearson, E. (2015). Policies and strategies to enhance the quality of early childhood. Education for All Global Monitoring Report 2015.

Tan, S., Zou, L., Wijaya, T. T., \& Dewi, N. S. S. (2020). Improving student creative thinking ability with problem based learning approach using hawgent dynamic mathematics software. Journal on Education, 2(4), 303-312. https://doi.org/10.31004/joe.v2i4.324

Wijaya, T. T., Ying, Z., Chotimah, S., Bernard, M., Zulfah, Z., \& Astuti, A. (2020). Hawgent dynamic mathematic software as mathematics learning media for teaching quadratic functions. Journal of Physics: Conference Series, 1592(1), 012079. https://doi.org/10.1088/1742$6596 / 1592 / 1 / 012079$

Wijaya, T. T., Ying, Z., \& Purnama, A. (2020). Using hawgent dynamic mathematic software in teaching trigonometry. International Journal of Emerging Technologies in Learning (IJET), 15(10), 215. https://doi.org/10.3991/ijet.v15i10.13099

Zhang, X., Zhou, Y., \& Wijaya, T. T. (2020). Hawgent dynamic mathematics software to teach line and angle. JNPM (Jurnal Nasional Pendidikan Matematika), 4(2), 237. https://doi.org/10.33603/jnpm.v4i2.3473

Zulnaidi, H., Oktavika, E., \& Hidayat, R. (2020). Effect of use of GeoGebra on achievement of high school mathematics students. Education and Information Technologies, 25(1), 51-72. https://doi.org/10.1007/s10639-019-09899-y 